\title{
Housing Financialization in the Global South: In Search of a Comparative Framework
}

Rodrigo Fernandez \& Manuel B. Aalbers,

KU Leuven, Division of Geography \& Tourism

\section{Paper under review}

\begin{abstract}
The financialization of housing in the Global South (GS) and peripheries of the Global North (GN) develops in different ways than in the GN because the mechanisms underlying and pushing financialization are fundamentally different. We argue that subordinated financialization in the GS is the contemporary form of uneven and combined development, shaped by the financialization of the GN. The recycling of GN excess liquidity in countries lower in the global money hierarchy has contributed to the growth of mortgage lending in the GS and peripheries of GN. With the macrocomparative perspective in our paper we provide a framework to rethink the relations between GN and GS in shaping distinct patterns of uneven and combined financialization, but also to rethink the varieties of capitalism and residential capitalism approaches. In the GS we can distinguish between at least two additional types: 'state-led market economies' (Nolke et al, 2015) and 'less-financialized market economies'.
\end{abstract}

Key words: subordinate financialization, global south, uneven and combined development, housing markets, mortgage lending, financial development

\section{Introduction}

Since the outbreak of the global-or North-Atlantic-crisis the financialization of housing has emerged as an important research theme in the field of housing studies (Aalbers, 2008; Lees et al., 2008). Financialization refers to "the increasing dominance of financial actors, markets, practices, measurements, and narratives at various scales, resulting in a structural transformation of economies, firms (including financial institutions), states, and households" (Aalbers, 2016: 2). In relation to housing, the literature has focused on financial actors, including banks, lenders, private equity and hedge funds (Fields, 2015; Wijburg et al., 2018); financial markets such as stock exchanges and the market for mortgage-backed securities (Aalbers and Engelen, 2015; Fernandez and Aalbers, 2016; Wainwright, 2012); financial practices including the provision of mortgages in foreign currencies and the use of derivatives beyond hedging risk (Aalbers et al., 2017; Halawa, 2015; Pósfai and Nagy, 2017); financial measurements such as credit scoring (Aalbers, 2005; Langley, 2008); and narratives and ideologies that frame homes as investments (Aalbers and Christophers, 2014; Ronald, 2008). An important shift in the literature has been the focus on not only mortgage debt and mortgage securitization, but also on rental housing, including (former) social housing (Wainwright and Manville, 2017; Wijburg and Aalbers, 2017), rent-stabilized housing (Fields, 2015; Teresa, 2016), student housing (Mendel, 2016; Revington and August, 2018), care homes (Horton, 2017; Killian, 2017), and single-family dwellings (August and Walks, 2018; Fields, 2018; 
Immergluck and Law, 2014), typically facilitated by government de- and re-regulation (Aalbers et al., 2011; Gotham, 2006; 2012; Waldron, 2018; Wijburg and Aalbers, 2017).

Although it is often assumed housing financialization is a Global North (GN) phenomenon, it is increasingly researched in the Global South (GS) (Aslan and Dinçer, 2018; Chua, 2015; Kutz and Lenhardt, 2016; Smart and Lee, 2003; Rolnik, 2013; see the other papers in this special issue), in particular in Brazil (Fix, 2011; Klink \& Stroher, 2017; Mosciaro, 2018; Pereira, 2017; Royer, 2014; Sanfelici and Halbert, 2018) and other parts of Latin America (López-Morales, 2016; Soederberg, 2015; Zapata, 2018), and has also been the subject of reports by two consecutive UN Special Rapporteurs on the Right to Adequate Housing (2012; 2017). The point is not that the financialization of housing is a global process per se, but that financialization is a multifaceted process and empirically speaking financialization in some domains may be happening alongside non-financialization in other domains.

We should therefore be cautious in concluding that financialization is everywhere or nowhere. From the literature on the GS, we know that in some countries the inflow of capital has resulted in booming housing and mortgage markets and that regulation has facilitated the spread of securitization and real estate investment trusts (REITs). The fact that some GS countries have underdeveloped and incomplete mortgage markets, securitization or REITs is sometimes mobilized to suggest that financialization in the GS as well as in the peripheries of the GN is fundamentally different, but this argument strikes us as overly simplistic. These characteristics are not necessarily unique to GS countries. Indeed, many GN countries also have not introduced mortgage securitization or REITs, or have only done so recently, often around the same time as many GS countries. The defining component of the financialization of housing is the transformation of residential real estat into a financial asset, opening channels for extraction by rentiers. Mortgage debt is the most common way in which this happens, but as we have illustrated above, not the only way. Furthermore, some rapid changes have taken and continue to take place in the GS. We need to take seriously these changes and understand how it is possible that very different countries experience-or push-similar trends or 'common trajectories' (Hay, 2004; Fernandez and Aalbers, 2016) in the early $21^{\text {st }}$ century, and in particular since the North-Atlantic financial and economic crisis of 2007-2009.

In this paper we seek to go beyond simplistic notions of 'the same' versus 'incomparable', and ask the question: Is the financialization of housing different in the GS and if so, how exactly is it different and why? Is there something that these countries have in common? In other words: how can we explain parallel developments in housing and finance in different GS countries, and how do these relate to developments in GN countries? We don't use 'relate' here as a synonym for 'compare' but rather to open up the debate to the possibility that differences between countries may not merely be the result of differences in economic development and path dependencies but that these differences themselves may be produced in the relations between different countries. That is, we wish to explore if the specific features of the financialization of housing in the GS are in part a result of the position of these countries within the global economy and therefore in relation to GN countries. We argue that the type of integration of the peripheries in hierarchical global monetary structures is the main mechanism to shape the process of subordinated financialization. This structural feature of core-periphery relations explains how the search for yield found its way into housing markets in the GS and 
peripheries of the GN on the back of QE policies in the GN. The impact, however was not uniform across coutries in the periphery. To understand the variety in outcomes, we need to look at institutional differences that mediate between global monetary relations and domestic housing markets.

Our goal is to present a first step in a systematic and comparative analysis of the financialization of housing in GS countries in light of a more general process of financialization. This paper presents a conceptual framework for analysis as well as the empirical tools and numbers, meant as a crucial step in the process of coming to grips with the role of housing finance in financialization processes outside the core countries of the GN. It does not discuss the politics of financialization within individual GS countries. This is of utmost importance and should not be ignored, but it is beyond the scope of this macro-comparative paper. Moreover, this important topic will be picked up in the other papers that make up this special issue. To facilitate a better understanding of housing financialization in the GS, it is important to read this paper in dialogue with these other papers. Our selection of countries in the GS is also inspired by the other abstracts that were accepted for this special issue, contributing to a comparative perspective between the different papers in this issue. ${ }^{1}$

Together, the different theories and statistics we present, feed our understanding of how and why the size of finance is proportionally smaller in the GS, something that is usually taken for granted. If we compare indicators of financialization, such as stocks of debt and financial assets and cross border capital flows, we find that the volume and depth of the financial sector differs widely across all political economies. Fundamentally, however, we find that finance, according to different indicators, is significantly larger in core GN countries, not only in nominal terms but most importantly, as share of its economy, compared to countries in peripheral GS countries (World Bank 2009, 2012; Fernandez 2017). This disproportionate weight of financial activity in the GN is a crucial part of the narrative detailing the character of the socio-historical transformation that financialization entails, that is, a rising dominance of finance. The question, however, is how to assess financialization in the GS, given the smaller financial footprint or even 'nonfinancialization'.

This requires us to rethink the usual indicators used to study expressions of financialization in the GS: the relevant indicators, mechanisms and expression of financialization may well be different. Comparatively low levels of mortgage debt, for instance, can still be an indication of a process of financialization of housing in developed countries, albeit confined to a specific demographic cohort and location. In studying the variegated nature of housing-centered financialization, we concluded that most countries in the GN and GS did not follow the type of financialization we witnessed in countries such as Spain, Ireland, the Netherlands, the UK and the US, that are characterized by extraordinary large mortgage markets and typically faced declining house prices during the financial crisis (Fernandez \& Aalbers 2016).

Conceptually, we revisit theories of uneven and combined development, core and (semi-)periphery, and subordinated financialization in order to come to an understanding of the structural differences between countries (section 2). We then apply these literatures to money flows and show how loose monetary policies in the GN took shape in response to the North-Atlantic financial crisis, thereby feeding a

\footnotetext{
${ }^{1}$ Not all accepted abstracts materialized as papers, which explains why we have included more countries than are covered in the other papers in this special issue.
} 
sharp rise in capital flows into select GS countries (section 3). As the literatures discussed in section 2 have barely focused on the issue of housing, we present empirical illustrations - typically based on publicly available, international statisticsto show the differences between GS and GN and, in particular, within the group of GS countries (section 4). We focus on the structural monetary conditions of countries in the periphery and how global capital flows can co-shape domestic forms of financialization In section 4 we also show how the patterns of financialization in the GS call for an extension of the model of varieties of capitalism. We stress that our analysis is only a first step in the analysis we call for.

\section{A framework to analyze financialization in the Global South}

As is also explained in the introduction to this special issue, the notions of Global South (GS) and Global North (GN) are inherently problematic. Like notions of developed and developing economies, industrial and non-industrial, core and periphery, or high- and low-income countries they present a binary view of the world, albeit sometimes with the addition of intermediate categories, such as the semiperiphery, newly industrialized or middle-income. This is not the place to deconstruct these concepts. One particular issue with these concepts and other master concepts is that no matter how problematic they may be, they can serve as useful shorthands in debates about differences between a large number of countries.

In this section, we will mobilize some of these 'older' concepts to help us understand contemporary patterns of financialization in what, for reasons of convenience, we call the GS. In sub-section 2.1 we briefly summarize the literature on the varieties of capitalism in the GS. In next next sub-section we revisit the concept of uneven and combined development (2.2) as it serves as a useful introduction to the concept of subordinated financialization (2.3), which could be considered a contemporary channel for uneven and combined development. Subordinated financialization was introduced in the literature to make sense of uneven power dynamics in financialization processes across countries. In subsection 2.4 we discuss the hierarchy of international money to explain subordinated financialization and its consequenses in an age of QE. In the next section we will apply these insights to analyze money flows between GN and GS and to understand the variagated outcomes.

\subsection{Varieties of capitalism in the Global South}

The varieties of capitalism literature was originally developed in, and apllied to, a GN context. In response of a wider debate (Becker 2013) to broaden the analytical tools of the varieties of capitalism approach to developing countries, Nölke et al (2015) introduced two additional national models of capitalism to capture distinctive institutional characteristics of emerging economies. The original typology, focused on developed economies, consisted of two varieties of capitalism, namely 'coordinated market economies' and 'liberal market economies'. In response to this dichotomy, the third model of 'dependent market economy' (Nölke and Vliegenthart, 2009) was developed to conceptualize the subordinated integration of East-Central European countries into the larger European economy. Central features of this model are a very open economy (as a result of external pressures), with a high share of foreign direct investments, which creates a dependency on foreign multinational corporations since domestic economic structures are disassembled. Dependent market economies become fully integrated in global value chains and the domestic financial sector 
becomes dominated by subsidiaries of foreign banks and other cross-border financial channels.

The fourth model Nolke et al (2015) distinguish, 'state-led market economies'-also known as 'state-permeated market economies' (Nölke and Claar, 2013)-is also positioned outside the core of the global economy but unlike 'dependent market economies', it is not dominated by foreign multinational corporations, but instead is characterized by a resilient and close-knit national elite, exercising power through an authoritative state-market nexus. ${ }^{2}$ In 'state-led market economies', corporate control by state institutions, through direct or indirect ownership is a key element of the national political economy. Also domestic banks and national financial institutions, such as pension funds, are central in providing credit. Moreover, the levels of foreign direct investment and foreign control over domestic industries is significantly lower compared to the other three models of capitalism (Nölke et al, 2015). Illustrations of this fourth national model of capitalism are Brazil, India and China and the authors argue the model is typical for large emerging economies.

This implies we may need at least a fifth type (and possibly more types) to account for smaller emerging economies. For the moment, we will side-lined this typology to focus on two other literatures: those on uneven and combined development, and subordinate financialization. After we have used that lens to make sense of patterns of financializaiton in the GS (section 3), we will, in section 4, revisit and expand the typology introduced here. The inclusion of the literature allows us to make sense of the empirical varieties of subordinate financialization in the GS.

\subsection{Uneven and combined development}

We can think of financialization in the GS as a process that resembles the notion of 'uneven and combined development'. More specifically: practices of financialization can co-exist in non-financialized institutional environments, as a result from crossborder interlinkages, that in time can have a broader implication for domestic political economies. Leon Trotsky coined the concept of 'uneven and combined development' to understand how Russia, a predominantly agrarian society, with pre-industrial power relations revolving around land ownership, could be the stage for a revolt of the working class. Class struggle belonged to a capitalist set of social relations rather than a feudal political economy, orthodox Marxist argued at the time. The thesis of uneven and combined development provided an explanation and justification for the Russian revolution (Van der Linden, 2007) and has been making a come-back in recent years (e.g. Antunes de Oliveira, 2019; Rosenberg, 2013).

The theory notes that capitalism is spatially variegated, leading to a process of uneven development across countries and regions. Yet, there are also pockets of advanced capitalist modes of production or institutional arrangements that co-exist in underdeveloped spaces of capitalism. Testimony to this historical 'law' were the highly politicized urban-based workers organizations that co-existed (combined) with a feudal tsarists Russian set of relations. Crucially these pockets of advanced capitalist relations were impelled and organized by cross-border capital flows from advanced localities. By 'importing' practices from advanced capitalist economies, less advanced economies may bypass intermediate developmental steps, a process

\footnotetext{
2 This type shares some characteristics with the hierarchical market economies, a type developed by Schneider (2013) for Latin America, but with less emphasis on the role of the state.
} 
also known as 'leapfrogging'. Trotsky provides the examples of Germany and the US, to explain how they could surpass the superior technologies of the UK:

\begin{abstract}
Although compelled to follow after the advanced countries, a backward country does not take things in the same order. The privilege of historic backwardness-and such a privilege exists-permits, or rather compels, the adoption of whatever is ready in advance of any specified date, skipping a whole series of intermediate stages. (...) The development of historically backward nations leads necessarily to a peculiar combination of different stages in the historic process. Their development as a whole acquires a planless, complex, combined character. (Trotsky, 1930/2017: 3, cited in Van der Linden, 2007: 147)
\end{abstract}

Another essential element of the notion of uneven and combined development is the contradictory nature of adopting an 'alien' capitalist practice from an advanced economy in a 'backward' economy (Trotsky [1930] 2017). Advanced capitalist modes of production strengthened the position of the feudal class and suppressed the advancement of the capitalist class. A final issue to address is the transformative capacity of the combined developments. It is not sufficient for 'islands' of developed forms of capitalism to be present in 'backward' economies. These practices need to be part of as well as produce wider socio-economic changes to imply a channel of uneven and combined development (Allinson \& Anievas, 2009).

\title{
2.3 Contemporary processes of uneven and combined development
}

The present face of financialization in developing countries echoes elements of the notion of uneven and combined development. Gabor, for example, analyzes how financialization developed in Romania, eventually evolving into ever stronger coreperiphery relations (Gabor, 2013). The external institutional pressures to take a shortcut towards neoliberal arrangements-lifting restrictions for foreign capital flows and deregulating markets-were overwhelming after the fall of communism in the 1990s. The National Bank of Romania became a Trojan horse in the process of achieving systemic change, its policies shaping the conditions for financialization. It led to two interrelated processes that would define the establishment of subordinate financialization. First, eliminating the favorable conditions for 'patient capital' and traditional banking. Second, orchestrating the influx of foreign banks and marketbased or non-deposit-based banking models (Gabor, 2012). We find similar islands of highly advanced practices of financialization in the built environment of Brazil (Fix, 2011; Klink \& Stroher, 2017; Mosciaro, 2018; Mosciaro et al., 2019; Pereira, 2017; Royer, 2014).

Another recent example of this principle is the World Bank agenda to 'maximize finance for development', which is a coordinated attempt to institutionalize the logic and calculative practices of global capital markets in low- and middleincome countries on the back of infrastructure projects (Gabor, 2018). The World Bank claims that it needs to create an asset class that appeals to 'sophisticated' institutional investors in order to attract sizeable funds to meet the targets set by the millennium goals. Part of the proposal is to securitize loans of multilateral development banks (MDBs), as specified in a G20 statement:

The MDBs should collaborate to enable system-wide securitization so as to mobilize institutional investors. Securitizing on a large scale, across the MDB system, will in effect create new asset classes and attract a wider range of investors. Equally important, planning for securitization downstream confers 
significant benefits upstream in the project cycle, by driving standardized documentation and commercial discipline. (G20, 2018: 4)

In the view of the World Bank this push towards adopting the language, logic and organizing principles of capital markets is a necessary move because public funds, donor countries and multilateral organizations fall short of US $\$ 2.5$ trillion annually to meet the investments that are required to achieve the millennium goals. The type of investments the World Bank promotes includes 'synthetic securitization', which was explicitly banned in the EU Capital Markets Union legislation (Gabor, 2018; Fernandez and Aalbers, 2017). The promotion of securitizing development projects is a compelling example of how advanced techniques from highly financialized contexts are channeled to low- and middle-income countries. Infrastructure projects in developing countries are transformed into liquid investments objects. These projects are often managed through public-private partnerships that privatize profits and publicize losses. In the process, risks and costs are passed on to public authorities while decision-making arrangements are essentially outside of democratic control (Griffits and Romero, 2018).

\subsection{The hierarchy of international money and subordinated financialization} Next to the particular channels that disseminate advanced practices of financialization to low- and middle-income countries, there are underlying structural elements that shape the process of financialization internationally. The embeddedness of low-income countries in uneven global financial and monetary relations creates a position of subordination. This relationship is rooted in historical colonial and imperial relations but also transcends these in several ways. The existing hierarchy of money restricts non-core countries to attract foreign loans denominated in the domestic currency. In his seminal work on the 'geography of money', Benjamin Cohen (1998) discusses how, from the start of the current phase of globalization in the 1970s, even developed economies faced problems in access to global capital markets in their own currencies.

One of the essential features of US hegemony was the creation of a monetary hierarchy, with the US dollar at the center. For the periphery this resulted in the inability to emit foreign debt in their respective domestic currencies. While debt on global markets can be denominated in US Dollars, Euros, British Pounds, Swiss Francs and Japanese Yen, it is far more difficult to sell domestic bonds to foreign investors in other currencies. For low-income countries this is simply impossible. GS countries are forced to borrow in a foreign currency, pushing them into subordinated relations. The role of the US Dollar in shaping the post-war US hegemonic structure is a central theme in much of the classic studies in international political economy, throughout the 1970s, 1980s and 1990s (Strange 1971; Cohen 1996, 2017; Helleiner 1994). The linkages of the dollar based global monetary hierarchy with developments in the periphery were less pronounced in these debates, except for the debt crises in the 1980s and late 1990s (Strange 1998).

The effect of having a lower ranked position in the global monetary pecking order was already discussed by Keynes (1929). In his investigation of the problems Germany faced in its payment of reparations after the World War I, Keynes spoke of a 'transfer problem'. It was not sufficient for the German state to raise taxes; it required foreign currency to repay its debts. This remains the central problem that countries towards the lower end of the monetary hierarchy face. Firstly, debt denominated in a foreign currency generates a reliance on liquidity conditions in 
other countries. This means that foreign economic conditions become dominant factors for the domestic macro-economic and financial cycle. When there is a slowdown in foreign capital inflows, domestic markets restrain the refinancing of foreign debt, thereby increasing overall risk. Secondly, and more importantly, there is a currency mismatch. Unlike debt denominated in domestic currencies, low-income countries need to expand exports in order to receive payments in foreign currencies that then allow them to pay off their debts.

Since the global financial crisis a number of heterodox, post-Keynesian and Marxist economists have theorized the notion of 'subordinated financialization'. This literature has tried to illustrate the broader systemic nature that pushed for a specific type of financialization across the GS (Kaltenbrunner \& Painceira, 2018a, 2018b; Hudson 2010; Lapavistas 2009b; Akyüz 2015; Karwowski \& Stockhammer 2017). A central part of their analysis shows how the interaction of the GS with the GN, under conditions of an uneven monetary system, shaped a process of subordinated financialization. One of the visible effects of the process subordinated financialization is the observation that since the turn of the century net financial movements have been flowing 'uphill', from the periphery to the core, and that this flow has accelerated since 2007 (Kaltenbrunner \& Painceira, 2018a; Lapavistas 2009a). The literature on subordinated financialization, points at the transformation that occurred after the debt crises in the late 1990s, resulting in an adjustment "from the accumulation of deficits to the accumulation of reserves", to explain the net transfer of capital from the south to the north (Painceira, 2008: p1). The accumulation of reserves was partly driven by the experiences of dealing with the IMF structural adjustment programs and the aspiration to attain sovereignty in the future (Rodrik 2006). The growing financial flows to the GS were another element that led to the expanded the accumulation of reserves by central banks in the GS.

In the housing studies literature, we find another example of subordinated financialization, namely mortgage loans denominated in foreign currencies in both Southern Europe in the late 20 ${ }^{\text {th }}$ century (Ave, 1996; Cassini, 1995; Villosio, 1995) and East-Central Europe in the early $21^{\text {st }}$ century (Bohle, 2014; Büdenbender and Lagna, 2018; Buszko \& Krupa, 2015; Rodik and Žitko, 2015). In both sub-continents and periods, devaluation of domestic currencies vis-à-vis the currency of the loan (DMark, Swiss Franc or Euro) resulted in increasing mortgage payments, financial stress and in some cases losing one's home. Rodrigues, Santos \& Teles (2016) and Pósfai \& Nagy (2017) have theorized these developments in terms of core and (semi)periphery relations, whereas Soederberg (2014) and Büdenbender, (2017) have argued that (semi-)peripheral countries absorb globally mobile capital from the core and thereby function as a spatial fix: "Subordinate financialization ... deepens global economic hierarchies through the one-sided export of financial profits from the semiperiphery to the core and the exposure of the former to the risks and discipline of financial markets" (Büdenbender \& Aalbers, 2019: 671).

\section{Subordinate financialization since the financial crisis}

In the previsous section we have presented subordindated financialization as the contemporary face of uneven and combined development. In this section that notion will used to analyze to money flows into the GS. Our argument here could be simplified as: loose monetary policies in the GN took shape in response to the NorthAtlantic financial crisis, thereby feeding a sharp rise in capital flows into select GS countries, which contributed to the financialization of housing in these countries. 
After the financial crisis the composition and size of capital flows to developing countries changed. Cross-border banking de-globalized in response to the crisis, the flight to quality and need to shrink balance sheets (BIS 2017). In this context of a decline in cross-border bank lending, the international bond market replaced bank loans as the main channel of funding towards developing countries (Caldentey 2017). This shift towards capital market-based finance fits a broader pattern that has been observed by the IMF (2015). While investment funds became ever more dominant players in global capital markets, loose monetary policies in the form of quantitative easing (QE) in developed economies injected trillions of dollars in the global financial system. The loose post-crisis monetary policies in the GN (US, EU and Japan) have injected roughly $\$ 11$ trillion into the global financial system between the collapse of Lehman Brothers in 2008 and 2018 (Yardini research 2018). This monetary response in the GN had a sizeable impact on the allocation of capital through bond markets to the GS (Apostolou 2017; Fernandez et al 2018).

According to statistics from the Bank for International Settlements (BIS), the stock of international bonds from Latin America and the Caribbean region increased from US\$297 billion in 2009 to US\$757 billion in 2017 (BIS 2017). In the Asia and Pacific region, the stock of international bonds increased from US $\$ 253$ billion in 2009 to US\$637 billion in 2017 (BIS 2017). Once the period of QE ends, these capital flows may reverse, leaving behind a stock of unpayable debt as we have already witnessed in Turkey. Figure 1 displays the increase in bonds across developed economies, Latin America and Asia. It clearly shows how, since the financial crisis, the outstanding value of international bonds in developed economies stalled and increased in Latin America. Developments in Asia were mainly pushed by growing Chinese foreign indebtedness. In a report by the World Bank (Lim et al, 2014: p 2) released prior to the ECB's QE program, the following was noted about reinvestments in developing countries:
Although QE was meant to be an expansionary monetary policy for the U.S. economy, the program had profound implications for developing countries. Faced with near zero-returns in the U.S. and other high-income countries- many of which were implementing unconventional monetary policies of their own-financial capital began to seek alternative sources of yield. Emerging economies, which had enjoyed heady growth rates and stable political- economic environments over the past decade, appeared to be an ideal investment alternative.

The World Bank report, based on data covering 60 developing countries, estimates that the contribution of QE from the US amounted to at least a 13 percent increase of cross-border capital flows of a total 62 percent increase during 2009-2013.

Economists at the Asian Development Bank (Morgan 2011) and the UN Economic Commission for Latin America and the Caribbean (Abeles et al 2018; Caldentey 2017) have made similar analyses.

Another critical element of the capital flows that emerged since the financial crisis is the rising share of corporate bonds and the decrease in the share of public bonds (Fernandez et al 2018). This made non-financial corporations the main channel of the increasing foreign liquidity into developing countries. Instead of higher levels of fixed capital formation (investment in the real economy) this increase was largely used for speculative purposes (carry trade). In the year 2000, governments represented 66 percent of total issuance of international bonds across all GS countries while non-financial corporations' debt issuance amounted to only 15 
Figure 1. Outstanding stock of international bonds, indexed $2000=100$

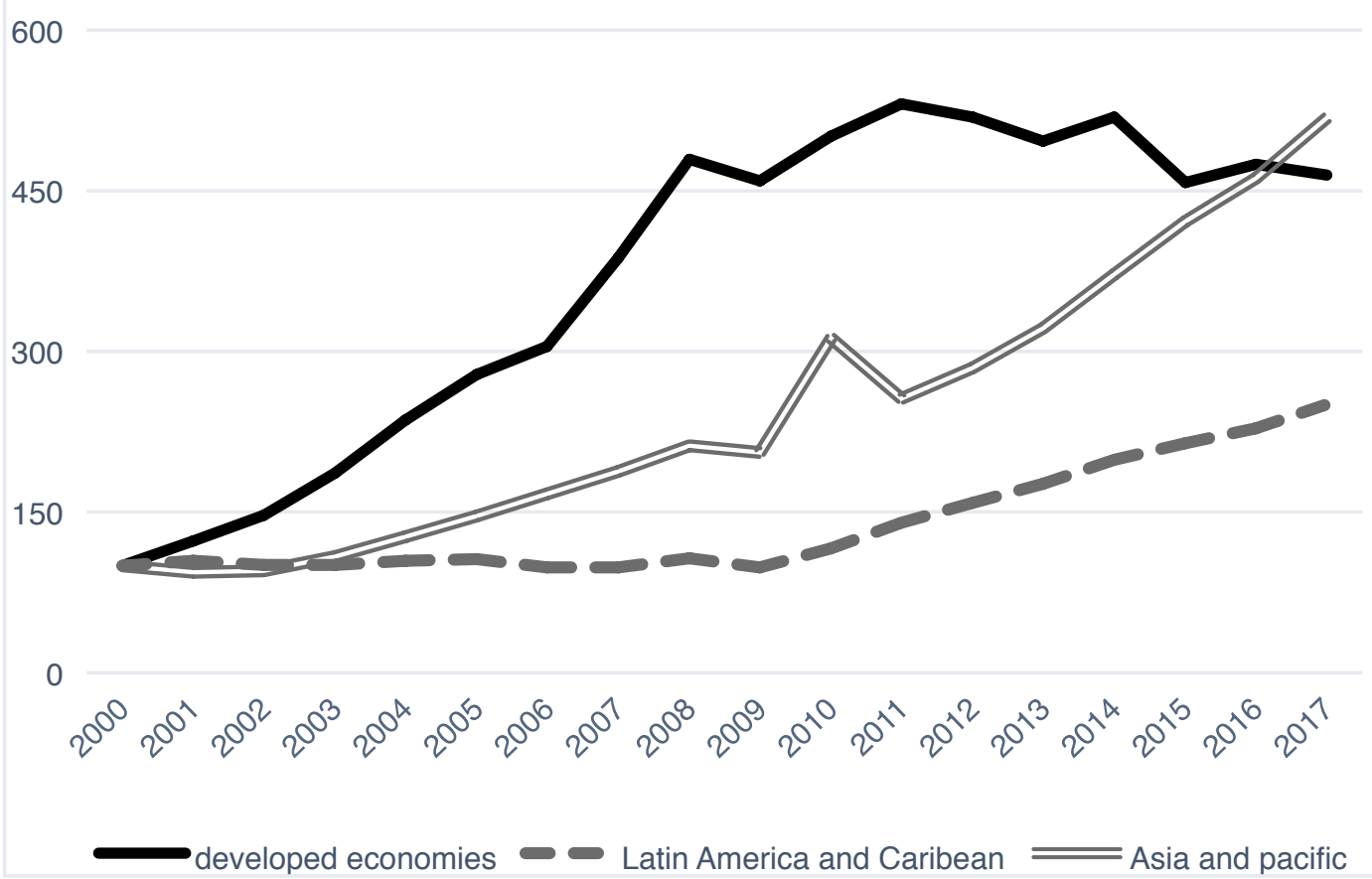

Source: calculations based BIS (2017)

percent of the total. In 2016 the proportions reversed, with governments representing 13 percent of borrowing, and non-financial firms more than 45 percent of total bond issuance (Fernandez et al. 2018: p 35).

Larger financial flows into developing countries, resulted in the need for central banks to 'sterilize' (i.e., to take out of circulation) this liquidity (Rodrik 2006; Hudson 2010; Kaltenbrunner \& Painceira, 2018a, 2018b; Lapavistas 2009b, 2009a).

Sterilization meant exchanging the incoming foreign liquid assets with domestic bonds to prevent inflation and to stabilize the exchange rate. In return for liquid assets, central banks offered domestic government bonds to domestic banks through repurchase agreements (repo). ${ }^{3}$ This monetary exchange in response of the large influx of foreign capital had a twofold effect on the domestic process of financialization of countries outside the core of the global economy.

Firstly, the build-up of reserves, by central banks from developing countries, resulted in the purchase of government bonds from mature economies, particularly the US (Rodrik 2006; Lapavistas 2009b). The purchase of foreign government bonds and the sale of domestic bonds, with a higher interest in the sterilization process, resulted in the net transfer of funds from GS to GN. This essentially means that the GS has been financing the deficits of the GN, in particular of the US, by purchasing its sovereign bonds. Dani Rodrik (2006) estimates the costs of these transactions to be in the range of $1 \%$ of GDP annually for developing countries. This calculation was made before the sharp increase in reserves held by developing countries that commenced after the financial crisis, pushed by QE policies, which implies it is very conservative estimate and costs are likely to be substantially higher. Figure 2 provides a nominal indication of the rise of the reserves of central banks across a

\footnotetext{
${ }^{3}$ A repo involves the sale of a security with an agreement to repurchase the same security back at a higher price at a later date. Repo transactions have become the main funding channel for banks in developed economies in the age of financialized capitalism.
} 


\section{Figure 2. Total reserves of central banks in billions of \$US Dollars}

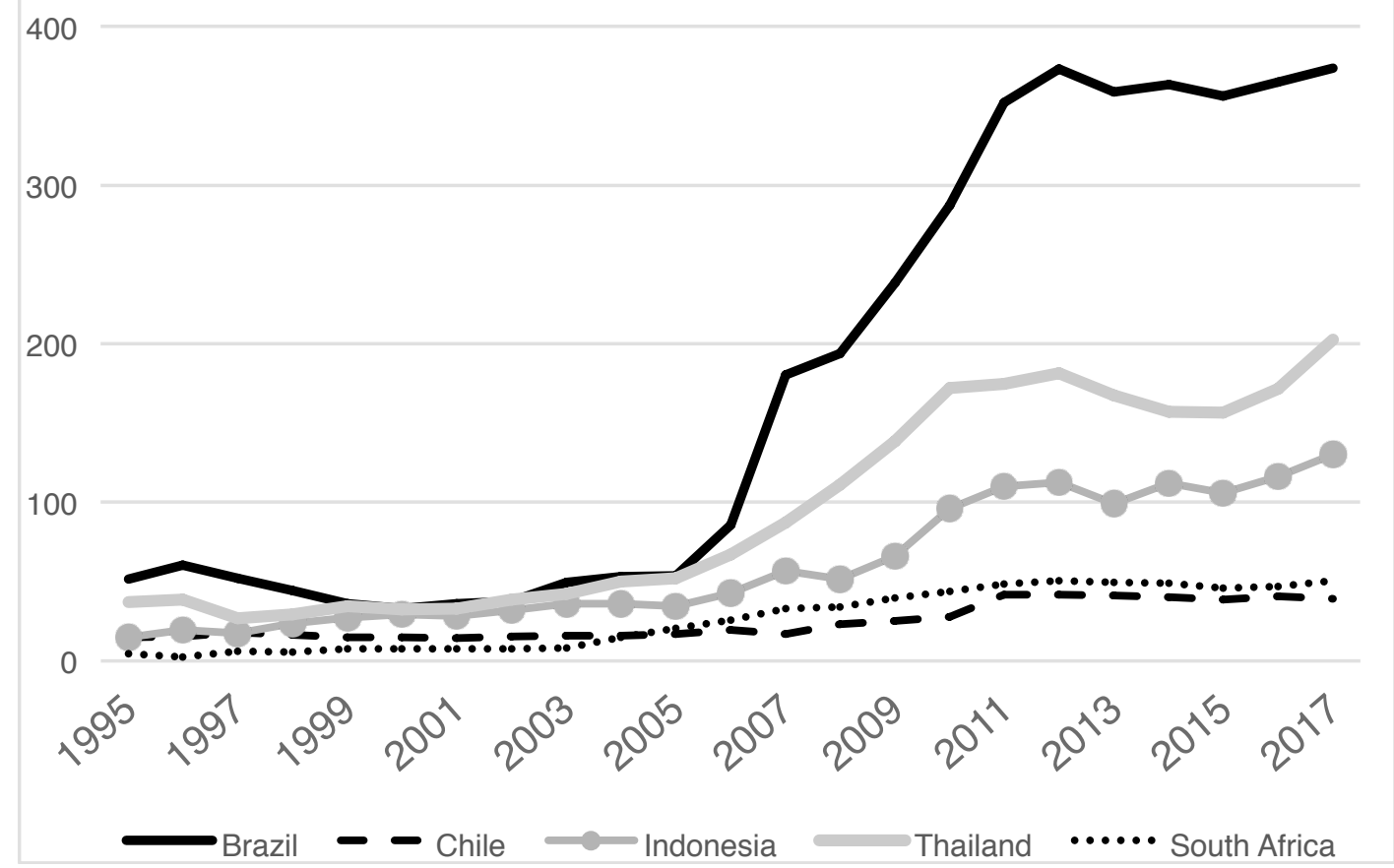

Source: World Bank financial development database

number of GS countries. It shows the geographically variegated impact of capital flows on the build-up of reserves, but also the synchronized rise in reserves since the mid-2000s, and accelerating directly after the financial crisis.

Secondly, the sterilization programs by central banks had important implications for the type of financialization it produced domestically. It created a liquid domestic bond and repo market, providing the essential infrastructure for local and foreign banks and intermediaries to engage in a broader set of financial transactions (Abeles et al 2018; Kaltenbrunner \& Painceira, 2016, 2018a, 2018b). The sterilization program by the Central Bank of Brazil, for example, took shape through repo transactions, which increased in tandem with the growing reserves, from $\mathrm{R} \$ 58$ billion in 2004 to R\$858 billion in 2014 (Kaltenbrunner \& Painceira 2016; p16). In Brazil domestic banks and financial intermediaries used the collateral that the central bank provided (bonds) to offer more loans, in particular mortgages to households (Kaltenbrunner \& Painceira, 2018a, 2018b). Figure 3 shows a chain of transactions starting with incoming financial flows, particularly after QE policies in the core, resulting in domestic banks receiving, government bonds from the central bank in exchange for the foreign liquidity. This chain continues all the way to housing. The bonds that the Central Bank of Brazil exchanged for excess liquidity, were used by the banks to extend more mortgages. This shows how capital markets and monetary policies in the core, directly created a pathway to extend credit to households in the GS. This process has been well documented in Brazil, where the growth in financial reserves was large, but there is reason to believe that other emerging economies may have responded to these external structural conditions in a similar manner. 
Figure 3. From international capital flows to domestic housing-centered financialization

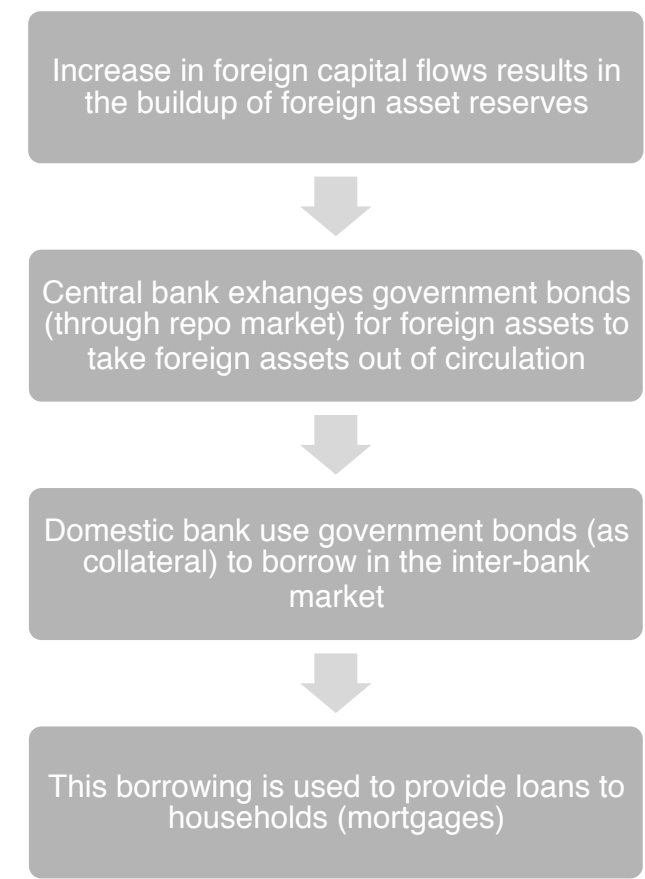

Source: adapted from Kaltenbrunner and Painceira (2016)

This is one of the faces of contemporary, subordinated financialization. In response to the loose monetary policy of developed economies, central banks in developing countries were obliged to do the contrary (diminish circulating liquidity), resulting in substantial losses for these countries. The bonds that were exchanged for liquidity through repo transactions led to the creation of a sophisticated financial infrastructure that allowed for the increase in mortgage debt. The structural element is the monetary hierarchy that requires central banks to behave this way in response to the post-crisis monetary landscape shaped by monetary authorities in the core.

In countries like Brazil, this new monetary landscape was complemented by housing policies, through which the state facilitated the financialization of housing. In particular, the Minha Casa Minha Vida (MCMV, My House My Life) housing program has become a vehicle of the Brazilian state to roll out housing finance on populations formerly excluded from it (Klink and Denaldi, 2014; Marques and Rodrigues, 2013; Soares et al., 2017). The first two phases of the program resulted in 3.9 million units by 2014 with the goal of building 27 million units by the end of 2018 (Governo do Brasil, 2015). Researchers have argued that the program, launched in March 2009, was primarily a subsidy for construction firms to avert the looming economic crisis (Fernandes and Novy, 2010; Fix, 2011; Rolnik, 2015; Sanfelici, 2013). Furthermore, although MCMV has created ownership rights for many households who lacked such rights, it has also sucked a lot of low- and moderate-income people into more mortgage debt than many can afford on (extremely) low-income and weak-if anylabor protection. Arguably, MCMV is the largest homeownership and construction/mortgage subsidy scheme ever launched in the world (Aalbers, 2019). 


\section{Typologies of financialization in the global south}

In the preceding section we have argued that the notion of uneven and combined development can be useful to understand recent money flows between GN and GS. Subordinated financialization is the contemporary face of uneven and combined development, a process we could also call 'uneven and combined financialization' This may result in the selective financialization of domestic economies in GS countries, including the rise of mortgage lending to specific sections of the population. In this section we will first analyze changes in private debt data as one possible indicator of housing financialization. In the second part we will revisit the varieties of capitalism model, that we have introduced in sub-section 2.1, and argue that it is necessary to expand this model in order to make sense of the GS. Not only do we need to understand the GS in relation to the GN, we also need to make sense of the variation between GS countries, as we also do for differences between GN countries.

\subsection{Private debt trends in the Global South}

Existing typologies of 'residential capitalism' (Schwartz and Seabrooke 2009;

Fernandez and Aalbers 2016; Blackwell and Kohl 2018) primarily examine variations across developed, high-income economies and do not capture the diversity in modes of financialization in less developed, low- to middle-income countries. A central denominator, nonetheless, of the 'generic' model of residential capitalism in the GS is a combination of relative low mortgage debt, high homeownership rates and low housing quality, including a large informal sector (Hansen and Vaa, 2004; Payne, 1989: Van der Linden, 1986). Comparative data on private debt levels show considerable differences, indicating that we need to account for variation or variegation across the GS, that is, there is no single GS model of residential capitalism, but a range of residential capitalisms. Private debt statistics not only include credit to households but also to non-financial corporate sectors. Private debt data is available for a longer period of time and covers more countries than the more household debt and mortgage debt data. Therefore it serves as a best-available proxy for tracking financialization in low- and middle-income countries.

In the past four decades there has been an increase in private debt as a share of GDP across all types of economies, as illustrated in Figure 4. Although overall private debt levels in low-income countries remain significantly lower than in highincome countries, we do see signs of a global 'common trajectory', moving towards higher debt levels (Thorsten et al, 2009). The growth rate of private debt is related to GDP per capita (Čihák et al 2012). Middle- and high-income countries have experienced a disproportionately larger increase in debt as shares of their respective economies. The result is that the range between top and bottom has increased: while private debt levels as shares of GDP in middle-income countries and low-income countries were, respectively, $49 \%$ and $10 \%$ in 1995, they increased to $106 \%$ and $20 \%$ respectively in 2016 . Yet, that implies that in the timespan of two decades debt levels have doubled in both types of countries, notwithstanding the crisis of 20072009. 
Figure 4. Domestic credit to private sector as share of GDP

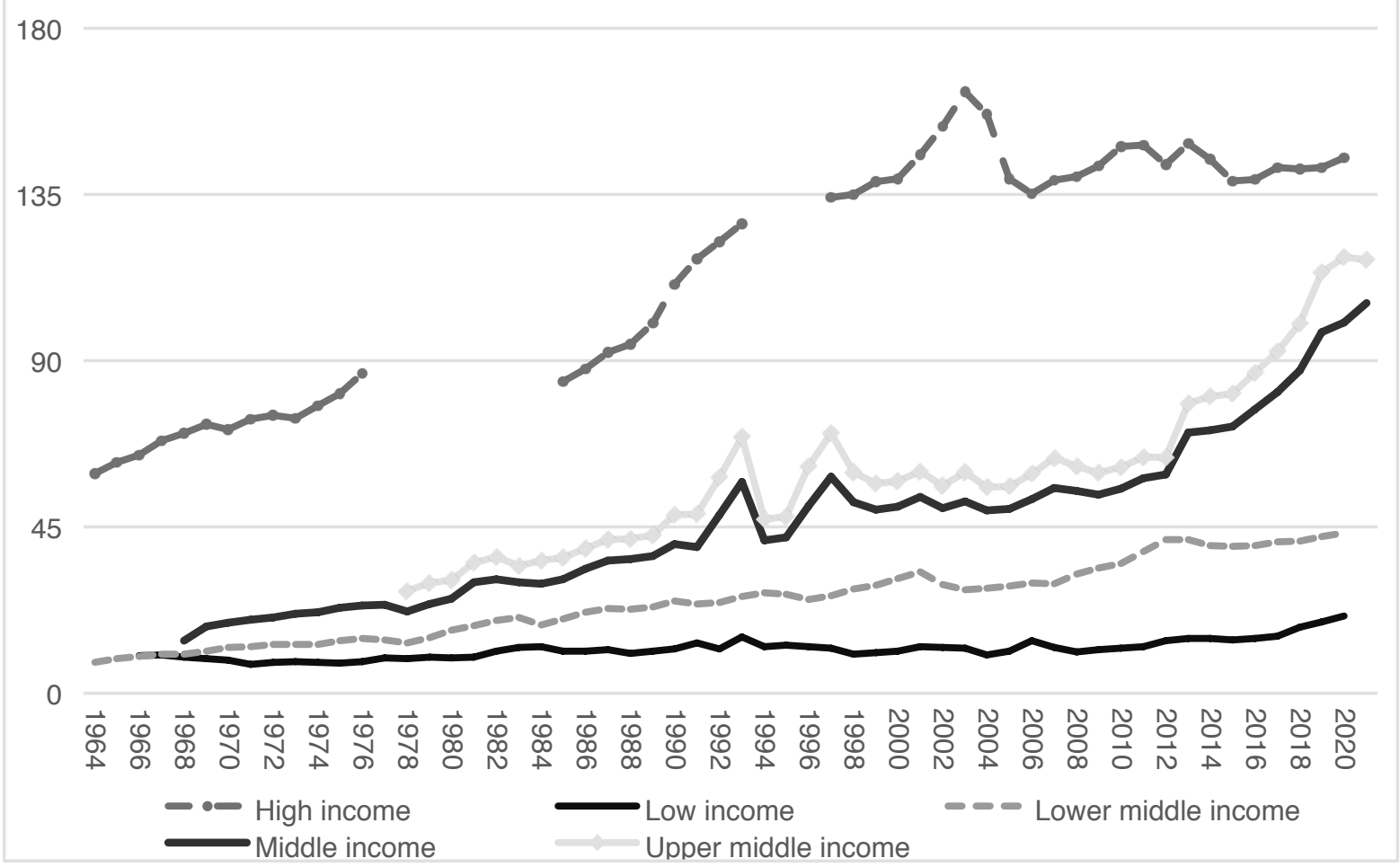

Source: World Bank, Global Financial Development data:

http://data.worldbank.org/indicator/FS.AST.PRVT.GD.ZS

Next to income levels, the World Bank and IMF also have established links with institutional characteristics that support financial development, such as legal characteristics (common law), corruption and the protection of deposits (Thorsten et al, 2009; Čihák et al 2012). However, the causal mechanisms between debt levels and institutional variables remain underdeveloped in this literature. The correlations between private debt levels and the broader concept of 'financial development' are strong, but the direction of causality is unclear and measurements of financial development include private debt, so the correlation is spurious. Data shows that the development of mature, diversified and internationally connected financial markets also implies higher debt levels (Thorsten et al, 2000; Čihák et al 2012). On the one hand, deeper and more diversified capital markets imply more efficient banks, better access to cross-border capital flows and more diversified cross border financial flows, create the right conditions for an increase in private debt levels. On the other, these structural transformations are triggered and pushed by an increase in the number of transactions and accumulated assets and debt.

The IMF indicator 'financial development', which is based on World Bank data, includes over 20 variables covering the depth of financial markets and institutions, the accessibility and efficiency of finance, such as profitability and lending rates (Svirydzenka 2016). The 'depth of financial markets' is measured by diverse types of debt, stock market capitalization, total assets of the financial sector and different indicators for international indebtedness. 'Accessibility' is measured by indicators of how companies can access credit and what type of collateral is needed. 'Efficiency' is measured through indicators of market concentration as well as bank profitability statistics (World Bank 2018). This bundle of diverse statistics, covering most countries in the world and including several decades, is the most comprehensive comparative measurement available for financial activities. 
The financial development index combines all these indicators into a single scale with a range from 0 to 1 (Svirydzenka 2016). Between 1992 and 2008, countries around the globe experienced an increasing score on this index. Mirroring private-debt-to-GDP portrayed in Figure 4, the financial development index shows that high-income countries experienced a larger increase, followed by middle-income countries. Low-income countries experienced a significantly smaller increase in the score on the financial development index, producing greater variation between countries. While the score on the index was around 0.1 for low-income countries and higher middle-income countries in 1980 and 0.3 for developed economies, the respective scores for these country groups were roughly, $0.1,0.3$ and 0.8 in 2008 (Svirydzenka 2016: 26). Interestingly, selected emerging economies, show higher scores on the financial development index compared to some developed economies. In 2008, Malaysia and Brazil, for instance, have a higher score than Portugal, Greece and New Zealand (Svirydzenka 2016: 27).

\subsection{Varieties of capitalism in the Global South}

The pattern in the scores on the financial development index, as presented in the previous sub-section, reiterates the typology developed by Nölke et al (2015) that we have introduced in section 2.1. We find that countries that are characterized in this typology as 'dependent market economies', tend to have a lower score relative to countries, in the same income category, that resemble 'state-led economies'. The group of 'state-led economies', if expanded to include economies such as Turkey, Malaysia, Thailand, Chile, Russia and South Africa (see figure 5), portrays higher scores on the financial development index, compared to East-Central European countries such as Bulgaria, Poland, Hungary, Czech Republic and Croatia.

This disparity only holds for middle- to high-income countries. Low-income countries all share a low score on the financial development index. India for instance, with a per capita income of about $20 \%$ of China, has a score on the financial development index of 0.39 . Although it is classified as a 'state-led economy' by Nölke et al (2015), India does not show signs of an extraordinary financial development. Furthermore, the distinction is far from being waterproof. There are several exceptions, such as Venezuela and Iran, possibly classifying as 'state-led economies', but having low scores on the financial development index. Furthermore, most countries cannot be classified straightforwardly in this simple dichotomy and would require a more detailed analysis. This suggests there may be two (sub-)types of 'state-led economies': one characterized by increasing financial development and one characterized by stable financial development. The latter group combines elements of Nölke et al. (2015) state-led and dependent market economies. An additional type may refer to non-state-led, low-income dependent economies, which would include low-income counties where the state has not been able to take the lead and financial development remains constrained. Table 1 summarizes the characteristics discussed and provides an overview of the separate institutional models that can be differentiated. 
Figure 5. GDP per capita in current \$ Dollars in 2013 and score on financial development index 2013

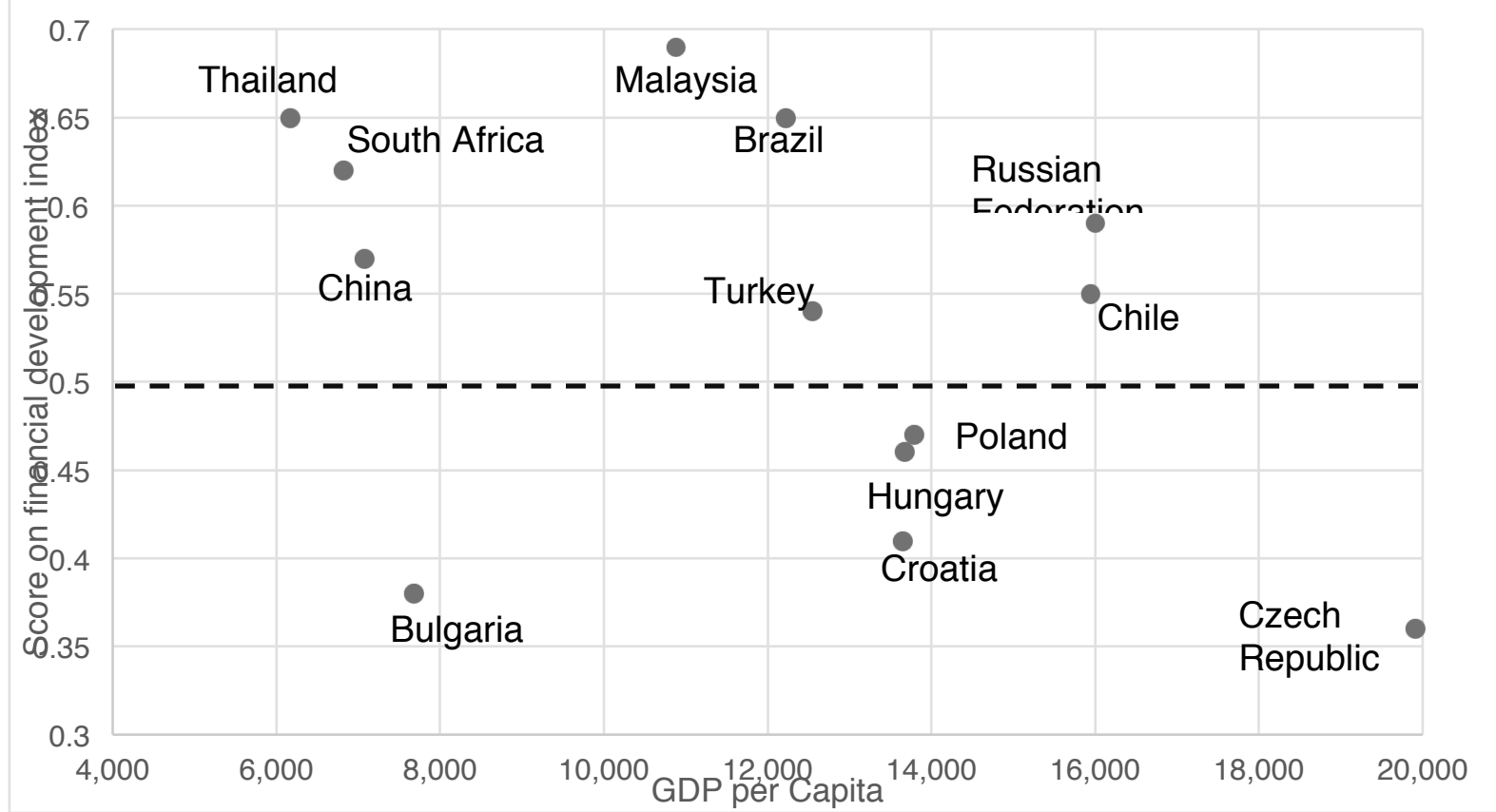

Source: calculations based on Svirydzenka 2016: $p$ 31-32 and World Bank data

Table 1. Typologies of financialization in (semi-)peripheral economies

\begin{tabular}{llll}
\hline $\begin{array}{l}\text { Institutional model } \\
\begin{array}{l}\text { Financial } \\
\text { development }\end{array}\end{array}$ & $\begin{array}{l}\text { State-led market } \\
\text { economies } \\
\text { Medium to high }\end{array}$ & $\begin{array}{l}\text { Dependent market } \\
\text { economies }\end{array}$ & $\begin{array}{l}\text { Less-financialized } \\
\text { market economies }\end{array}$ \\
\hline $\begin{array}{l}\text { Private debt } \\
\text { levels }\end{array}$ & Medium & Medium & Extremely low \\
\hline $\begin{array}{l}\text { Position in global } \\
\text { hierarchy of } \\
\text { money }\end{array}$ & Medium & Medium & Lowest \\
\hline Income level & Low to medium & Low to medium & Low \\
\hline
\end{tabular}

If we move to the field of housing finance, which is part of these broader developments in finance and financial development but typically largely ignored in the literature on financial development, we observe similar patterns. Table 2, displays key housing finance statistics for the countries included in this special issue. Please note that some data, e.g. homeownership rates, are difficult to compare because informal housing makes up a large part of the housing stock in many of these countries and may be included or excluded from the official homeownership rate. It becomes clear that income levels are essential to understand levels of mortgage debt. Several housing finance elements move together, such as the lending rate, income levels and mortgage-debt-to-GDP ratios, essentially reaffirming the multidimensional character of finance. Indeed, for mortgage debt to increase in proportion to GDP, the efficiency of the banking sector, the level of cross-border connectivity of capital markets and diversity of financial intermediaries are imperative. 
Table 2. Selected housing finance indicators

\begin{tabular}{|c|c|c|c|c|c|c|c|c|c|c|}
\hline & $\begin{array}{r}\text { Mort- } \\
\text { gage } \\
\text { debt to } \\
\text { GDP }\end{array}$ & Year & $\begin{array}{r}\text { Home- } \\
\text { owner- } \\
\text { ship } \\
\text { rate }\end{array}$ & Year & $\begin{array}{c}\text { Interest } \\
\text { rate }\end{array}$ & Year & $\begin{array}{r}\text { Typical } \\
\text { LTV } \\
\text { Ratio }\end{array}$ & Year & $\begin{array}{l}G D P \\
P P P\end{array}$ & Year \\
\hline Argentina & 0.35 & 2016 & 69 & 2010 & 31.32 & 2016 & N.A. & & 20047 & 2016 \\
\hline Brazil & 9.14 & 2015 & 68 & 2015 & 12.62 & 2015 & 60 & 2015 & 15614 & 2015 \\
\hline Cambodia & 5.64 & 2016 & 85 & 2013 & N.A & & 65 & 2016 & 3711 & 2016 \\
\hline Chile & 21.39 & 2015 & 83 & 2012 & 5.51 & 2015 & 80 & 2015 & 23459 & 2015 \\
\hline China & 18.37 & 2015 & 80 & 2012 & 4.35 & 2015 & 80 & 2015 & 14107 & 2015 \\
\hline Ecuador & 2.11 & 2014 & 72 & 2006 & 14.93 & 2007 & 70 & 2015 & 11263 & 2015 \\
\hline Egypt & 026 & 2013 & 37 & 2011 & 13.6 & 2016 & 70 & 2007 & 12113 & 2016 \\
\hline India & 7.67 & 2015 & 87 & 2011 & 10.01 & 2015 & 80 & 2016 & 6161 & 2015 \\
\hline Indonesia & 2.85 & 2016 & $67 \dagger$ & 2007 & 11.89 & 2016 & 85 & 2016 & 11720 & 2016 \\
\hline Kenya & 3.24 & 2015 & 18 & 2009 & 16.09 & 2015 & 90 & 2014 & 3207 & 2015 \\
\hline Mexico & 9.92 & 2016 & 64 & 2015 & 3.42 & 2015 & 80 & 2016 & 17905 & 2016 \\
\hline $\begin{array}{l}\text { South } \\
\text { Africa }\end{array}$ & 18.35 & 2015 & $\begin{array}{r}53 / \\
62\end{array}$ & $\begin{array}{l}2014 / \\
2012\end{array}$ & 9.42 & 2015 & N.A. & & 13165 & 2015 \\
\hline $\begin{array}{l}\text { South } \\
\text { Korea }\end{array}$ & 31.05 & 2015 & 56 & 2005 & 3.53 & 2015 & 56 & 2012 & 36511 & 2015 \\
\hline Taiwan & 41.13 & 2016 & 84 & 2016 & 2.61 & 2016 & 60 & 2016 & 47811 & 2016 \\
\hline Turkey & 7.80 & 2016 & $67^{*}$ & 2011 & N.A. & & 75 & 2015 & 20437 & 2015 \\
\hline Uruguay & 3.96 & 2015 & 83 & 2011 & 15,84 & 2015 & N.A. & & 21506 & 2015 \\
\hline
\end{tabular}

Source: Housing Finance Information Network; World Bank data. *Turkish statistical institute (2013) http://www.turkstat.gov.tr/PreHaberBultenleri.do?id=15843; Statistics SA's Household Survey 2014, respectively Economists.co.za, 2013; ᄀMECOVI, 2006;

thttp://www.hofinet.org/countries/description.aspx?regionID=2\&id=76 (urban households only)

Although loan-to-value restrictions have limited the growth of mortgage lending in some GN countries, we expect that such restrictions would be less effective in many GS countries where the growth is already bounded by high interest rates, e.g. $16 \%$ in Kenia, 12\% in Indonesia and $10 \%$ India. Of course, high and fluctuating interest rates can also stabilize at a lower level, as happened in Southern European countries, largely as a result of their integration in the EU. Yet, high interest rates in domestic currencies may also be a push factor for lenders to offer mortgage loans in foreign currencies, as we have seen in both Southern and East-Central Europe, thereby trading high interest payments for high currency risks. This is a significant risk, in particular in countries where the expansion of finance co-exists with the persistence of high interest rates. 


\section{Figure 6. Income per capita PPP and mortgage as share of GDP.}

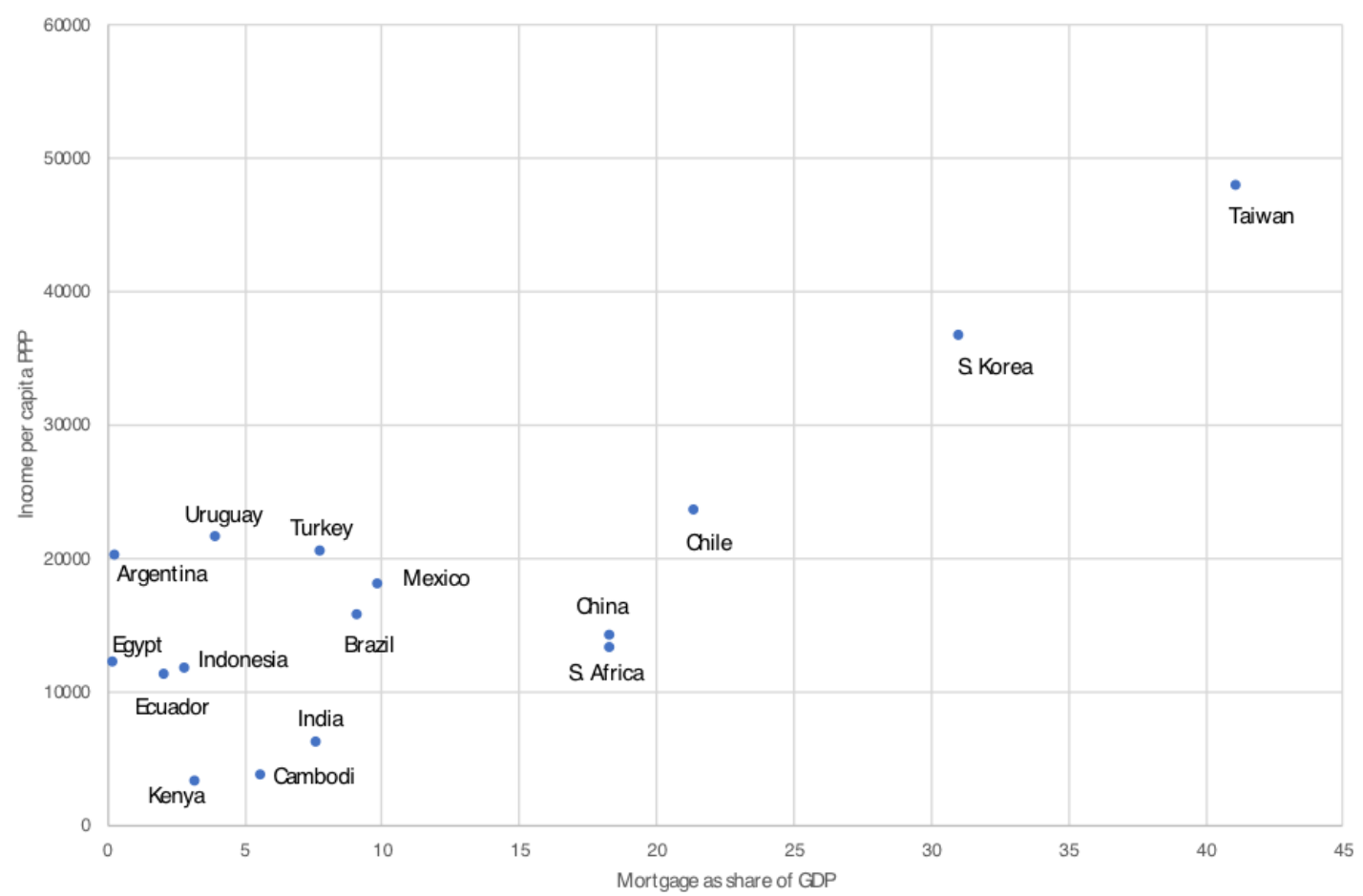

Source: Housing Finance Information Network; World Bank data

The mortgage-debt-to-GDP data, portrayed in figure 6 , suggest that the relation between income and mortgage ratios becomes stronger above a certain threshold. This is consistent with financial development data, which shows that the development of financial activities is not linear, but increases disproportionately in high-income economies. These different types of data show that income levels, as well as the type of integration into the global economy, are part of shaping the level of financialization in developing countries. As a result, intra-GS differences, both in terms of debt levels and of 'financial development' have amplified in the age of financialization, reflecting the problematic nature of focusing on the GS as a single category.

\section{Conclusion: Uneven and combined financialization}

The financialization of housing in the Global South (GS) and peripheries of the Global North (GN) develops in different ways than in the core of the GN because the mechanism underlying and pushing financialization is fundamentally different. To understand the origins and workings of this mechanism, we need to understand the uneven relations between different countries in the world, how they have changed under conditions of financialization and how liquidity and capital flows from the GN feed financialization in the GS.

In this paper we have argued that subordinated financialization is a contemporary form of uneven and combined development. Practices of financialization can co-exist in otherwise non-financialized institutional contexts, but over time these practices can become launching grounds for a wider financialization of the economy, extending to different sectors, to different places or to different classes of people. We find advanced financial practices, for example in the 
securitization of infrastructure and foreign currency mortgage loans, along otherwise only moderately financialized developments_clear signs of what we could also name 'uneven and combined financialization'.

It is important to understand that this pattern of financialization in the GS is, at least in part, shaped by the financialization processes in the GN. The more general development of the financialization of the economies of many GN countries-not limited to mortgage lending but extending into a range of non-financial sectors-has resulted in overaccumulation and crisis. Part of the 'solution' to the North-Atlantic financial crisis of 2007-2009 has been the rolling out of loose monetary policies, such as quantitative easing, from the US to the EU and Japan. Among, many other developments, this resulted in growing financial flows to select GS countries. The excess liquidity that was created as a result of this, needed to be managed by the central banks of GS countries, and one typical way to do so was to 'sterilize' this liquidity by exchanging incoming foreign liquid assets with domestic bonds, in order to prevent inflation and stabilize the exchange rate. The build-up of reserves by the central banks of the GS resulted in the purchase of government bonds from GN countries, thereby financing the deficits of the GN, in particular the US. But the sterilization programs by GS central banks also created a liquid domestic bond and repo market, thereby providing the essential infrastructure for banks to expand lending activities, in particular mortgage lending (see figure 3). Essentially, central banks in GS countries that where flooded by foreign liquidity, were forced to do the opposite from what the central banks in the core did, namely decrease liquidity. Paradoxally, this intervention created favorable conditions for domestic banks to provide mortgages.

Although we have mobilized the idea of core-periphery relations to make sense of global financial flows in general and the financialization of the housing markets of the GS in particular, our paper could also be read as a critique of the traditional core-periphery literature, which primarily revolves around trade and foreign direct investment. Our argument is that contemporary core-periphery relations are also-and perhaps predominantely_shaped by financial flows and debt relations, i.e. subordinated or uneven and combined financialization. Housing plays a double role in this process. On the one hand, subordinated financialization takes the form of rapidly developing mortgage markets; on the other, the inflow of capital is aligned with national policies to promote homeownership for the middle and in some cases also working classes. Together, these global and national tendencies result in the growth of mortgage homeownership.

Different countries respond differently to the combined challenges of liquidity flows, money hierarchies, and of course national political and economic realities. In order to understand the particular 'national' strategies that GS countries take, it is necessary to study these countries both individually and in a comparative-institutional perspective, something that is beyond the scope of our paper, but that is the focus of the other papers that make up this special issue. With the macro-comparative perspective in our paper we have provided a framework that not only helps us to rethink the relations between GN and GS in shaping distinct patterns of uneven and combined financialization, but also to rethink the varieties of capitalism (VoC) and residential capitalism approaches.

The original VoC typology focused on a dichotomy of developed economies: 'liberal market economies' and 'coordinated market economies'. A third type, 'dependent market economies', was added to make sense of the subordinated integration of East-Central Europe into the larger European economy (Nölke and 
Vliegenthart, 2009). More recently, a fourth type, 'state-led market economies', was added for large GS economies that, contrary to dependent market economies, are not dominated by foreign multinational corporations but characterized by a national elite that exercises power through an authoritative state-market nexus (Nolke et al, 2015). Our analysis of financial data shows that these state-led market economieswhich in our perspective include not only large but also mid-sized GS economieshave a higher level of economic development than the dependent market economies of East-Central Europe.

Our analysis also suggests that we need at least a fifth type to account for other GS countries in which financial development in general, and the growth of mortgage debt in particular, have been more moderate. It could be hypothesized that this fifth group would include countries that are not or less favored as places to recycle the liquidity produced in the GN. In other words, what distinguishes these countries from state-led market economies is an even lower position in the global hierarchy of money. This fifth type is not necessarily non-state-led and we also cannot conclude that they are less (or more) dependent than the countries of EastCentral Europe. In fact, this group may be too diverse to consider it one type and give it one joint label. Future research on the countries will need to establish if they can be captured as a distinct group. For now, we dub them 'less-financialized market economies'. Indeed, we do not label the fifth type as 'non-financialized'. Although financial development remains constrained, debt levels still have doubled between 1995-2016, suggesting financialization is not averted but taking place in limited sectors, places and classes, underlining our 'uneven and combined financialization' argument.

In this paper we have presented a first step in a systematic and comparative analysis of the dynamics of financialization in GS countries. Housing is part of these finance-dominated processes as object, collateral and socio-political domain. To understand the financialization of housing, we belief that we need to understand the broader context in which it is embedded. A lot of work remains to be done, not only to understand the different types of (residential) capitalism, but also to understand the national politics that to a large extent co-shape patterns of uneven and combined financialization. Furthermore, our analysis has primarily focused on mortgage finance; future research would also need to present a systematic and comparative analysis of mortgage securitization, residential REITs and other forms of housing financialization. Such studies could build on our conclusion that the type of integration of the periphery in hierarchical global monetary structures is the key mechanism to shape the process of subordinated financialization. 


\section{References}

Aalbers MB (2008) The financialization of home and the mortgage market crisis. Competition and Change 12(2): 148-166.

Aalbers MB (2016) The Financialization of Housing: A Political Economy Approach. London: Routledge.

Aalbers MB (2017) The variegated financialization of housing. International Journal of Urban and Regional Research 41(4): 542-554.

Aalbers, MB (2019). Financial geographies of real estate and the city: A literature review. Financial Geography Working Paper \#21: http://www.fingeo.net/fingeo-working-paperseries/.

Aalbers MB and Christophers B (2014) Centring housing in political economy. Housing, Theory and Society 31(4): 373-394.

Aalbers MB and Engelen E (2015) The political economy of the rise, fall, and rise again of securitization. Environment and Planning A 47(8): 1597-1605.

Aalbers MB, Engelen E and Glasmacher A (2011) Cognitive closure' in the Netherlands: mortgage securitization in a hybrid European political economy. Environment and Planning A 43(8): 1779-1795.

Aalbers MB, Van Loon $\mathrm{J}$ and Fernandez R (2017) The financialization of a social housing provider. International Journal of Urban and Regional Research 41(4): 572-587.

Abeles, M., Caldentey, E, P. \& Valdecantos (2018). Introdcuccion. Chapter In: Abeles, M., Caldentey, E, P. \& Valdecantos (Editors) (2018). Estudios sobre financierizacion en America Latina. Santiago de Chile, CEPAL Naciones Unidas

Akyüz, Y. (2011). Capital Flows to Developing Countries in a Historical Perspective: Will the Current Boom End With a Bust? South Centre. Research paper. Accessed online 1-112018: https://www.southcentre.int/wp-content/uploads/2013/05/RP37_Capital-Flows-todeveloping-countries_EN.pdf

Akyüz, Y. 2015. Internationalization of Finance and Changing Vulnerabilities in Emerging and Developing Economies. South Centre.

Allinson, J.C \& Anievas, A. (2009). The uses and misuses of uneven and combined development: an anatomy of a concept. Cambridge Review of International Affairs, 22:1, 47-67

Antunes de Oliveira, F. (2019) The rise of the Latin American far-right explained: dependency theory meets uneven and combined development. Globalizations DOI: 10.1080/14747731.2019.1567977.

Apostolou, A., and Beirne, J. (2017). Volatility spillovers of Federal Reserve and ECB balance sheet expansions to emerging market economies. ECB Working Paper Series, 2017, No 2044, p. 3.

Aslan AS and Dinçer I (2018) The impact of mortgage loans on the financialization process in Turkey. Planlama 28(2): 143-153.

August $M$ and Walks A (2018) Gentrification, suburban decline, and the financialization of multi-family rental housing: The case of Toronto. Geoforum 89: 124-136.

Ave, G. 1996. Urban land and property markets in Italy. London: UCL Press.

BIS (2017). Debt securities statistics. Accessed online 14-9-2017: http://www.bis.org/statistics/secstats.htmBIS (2017) Financial deglobalisation in banking? BIS Working Papers No 650

Blackwell T and Kohl S (2018) Historicizing housing typologies: beyond welfare state regimes and varieties of residential capitalism. Housing Studies DOI:10.1080.02673037.2018.1487037.

Bohle D (2014) Post-Socialist Housing Meets Transnational Finance: Foreign Banks, Mortgage Lending, and the Privatization of Welfare in Hungary and Estonia. Review of International Political Economy 21(4): 913-948.

Bonizzi, B. (2017). International financialisation, developing countries and the contradictions of privatised Keynesianism. Economic and Political Studies, 5:1, 21-40

Büdenbender MA (2017) New spaces of capital: the real estate/financial complex in Russia and Poland. PhD thesis. Leuven: KU Leuven. 
Büdenbender M and Aalbers MB (2019) How subordinate financialization shapes urban development The rise and fall of Warsaw's Służewiec Business district. International Journal of Urban and Regional Research 43:4: 666-684.

Büdenbender M and Lagna A (2018) Financial innovation and mortgage markets in Russia and Poland. Paper under review.

Buszko, M., \& Krupa, D. (2015). Foreign currency loans in Poland and Hungary-a comparative analysis. Procedia Economics and Finance, 30, 124-136.

Casini, M. 1995. I/ Credito Immobiliare. Milano: Banca d'Italia.

Chua BH (2015) Financialising public housing as an asset for retirement in Singapore. International Journal of Housing Policy 15(1): 27-42.

Čihák, M., Demirgüç-Kunt, A., Feyen, E., \& Levine, R. (2012). Benchmarking Financial Systems around the World. Policy Research Working Paper, 6175.

Cohen, B. J. (1996) 'Phoenix risen: the resurrection of global finance', World Politics 48(2): 268-96.

Cohen, B. J. (1998) The Geography of Money, Princeton, NJ: Princeton University Press.

Cohen, B. J. (2017). The IPE of money revisited. Review of International Political Economy, 24:4, 657-680

Demir, F. (2009). "Capital Market Imperfections and Financialisation of Real Sectors in Emerging Markets: Private Investment and Cash Flow Relationship Revisited." World Development 37(5): 953-964.

E.P. Caldentey (2017). Quantitative Easing: Changes in global liquidity and financial instability. Post Keynesian economics study group, working paper 1701, accessed online 1-12-2018: http://www.postkeynesian.net/downloads/workingpapers/PKWP1701.pdf

Ebenau, M. (2012). Varieties of Capitalism or Dependency? A Critique of the VoC Approach for Latin America. Competition \& Change, 16(3), 206-223. Fernandes AC and Novy A (2010) Reflections on the unique response of Brazil to the financial crisis and its urban impact. International Journal of Urban and Regional Research 34(4): 952-966.

Fernandez, R. (2017). Stylized facts from housing and finance-How do they relate across space and time? Financial Geography Working Paper \#1: http://www.fingeo.net/fingeoworking-paper-series/.

Fernandez R and Aalbers MB (2016) Financialization and housing: Between globalization and varieties of capitalism. Competition and Change 20(2): 71-88.

Fernandez R and Aalbers MB (2017) Capital Market Union and residential capitalism in Europe: Rescaling the housing-centred model of financialization. Finance and Society 3(1): 32-50.

Fernandez, R., Bortz, P and Zeolla, N (2018). The politics of quantitative easing: A critical assesment of the harmful impact of European monetary policy on developing countries. SOMO report.

Fields D (2015) Contesting the financialization of urban space: community organizations and the struggle to preserve affordable rental housing in New York City. Journal of Urban Affairs 37(2): 144-165.

Fields D (2018) Constructing a new asset class: Property-led financial accumulation after the crisis. Economic Geography 94(2): 118-140.

Fix M (2011) Financeirização e Transformações Recentes no Circuito Imobiliário no Brasil. PhD thesis. Campinas: Universidade Estadual de Campinas.

G20 (2018). G20 Eminent Persons Group (EPG) on Global Financial Governance: Update for the G20 Meeting of Finance Ministers and Central Bank Governors Accessed online 28-11-2018:

https://g20.org/sites/default/files/media/epg_chairs_update_for_the_g20_fmcbgs_meeti ng in buenos aires march 2018.pdf

Gabor, D (2018). The World Bank pushes fragile finance in the name of development. Financial Times 29-10-2018. Accessed online 28-11-2018:

https://ftalphaville.ft.com/2018/10/29/1540799191000/The-World-Bank-pushes-fragilefinance-in-the-name-of-development-/ 
Gabor, D. (2012a). Managing Capital Accounts in Emerging Markets: Lessons from the Global Financial Crisis, Journal of Development Studies, 48:6, 714-731

Gabor, D. (2012b). The Road to Financialization in Central and Eastern Europe: The Early Policies and Politics of Stabilizing Transition, Review of Political Economy, 24:2, 227249

Gabor, D. (2013). The Financialisation of the Romanian Economy: from Central Bank-led to Dependent Financialization. Financialisation, Economy, Society \& Sustainable Development (FESSUD) Project.

Gotham KF (2006) The secondary circuit of capital reconsidered: Globalization and the U.S. real estate sector. American Journal of Sociology 112(1): 231-275.

Gotham KF (2012) Creating liquidity out of spatial fixity: The secondary circuit of capital and the restructuring of the US housing finance system. In: Aalbers MB (ed.) Subprime Cities: The Political Economy of Mortgage Markets. Oxford: Wiley-Blackwell, 2552. Governo do Brasil (2015) Minha Casa Minha Vida atinge 3,857 milhões de moradias. http://www.brasil.gov.br/editoria/infraestrutura/2015/05/minha-casa-minhavidaatinge-3-857-milhoes-de-moradias (accessed August 26, 2018).

Griffiths, J., and Romero, M, J. (2018). Three compelling reasons why the G20's plan for an infrastructure asset class is fundamentally flawed. Eurodad, Brussels, June 2018. Accessed online 28-11-2018: https://eurodad.org/files/pdf/1546931-three-compellingreasons-why-the-g20-s-plan-for-an-infrastructure-asset-class-is-fundamentally-flawed1533475091.pdf

Halawa M (2015) In New Warsaw: Mortgage credit and the unfolding of space and time. Cultural Studies 29(5-6): 707-732.

Hall, S. (2012) Geographies of money and finance II: financialization and financial subjects. Progress in Human Geography 36.3 403-11.

Hansen, K.T. \& Vaa, M. (Eds.). (2004). Reconsidering informality: Perspectives from urban Africa. Uppsala: Nordic Africa Institute.

Hay, C. (2004) Common trajectories, variable paces, divergent outcomes? Models of European capitalism under conditions of complex economic interdependence. Review of International Political Economy, 11(2), 231-261.

Helleiner, E. (1994) States and the Re-emergence of Global Finance: from Bretton Woods to the 1990s. Ithaca, Cornell University Press.

Horton AE (2017) Financialisation of Care: Investment and Organising in the UK and US. Doctoral dissertation. London, Queen Mary University of London.

Hudson, M (2010). How Brazil Can Defend Against Financialization and Keep Its Economic Surplus for Itself. The Levy Economics Institute, Working Paper, 634.

Immergluck D and Law J (2014) Investing in crisis: The methods, strategies, and expectations of investors in single-family foreclosed homes in distressed neighborhoods. Housing Policy Debate 24(3): 568-593

IMF (2015). The asset management industry and financial stability. Chapter 3 of Global Financial Stability Report, April 2015. Washington DC, IMF

IMF (International Monetary Fund) (2015). Corporate Leverage in Emerging Markets - A Concern? . Global Financial Stability Report. IMF (International Monetary Fund). October 2015: 83-114.

Kaltenbrunner, A. and Painceira, J.P. (2015), Developing Countries' Changing Nature of Financial Integration and New Forms of External Vulnerability: The Brazilian experience. Cambridge Journal of Economics, 39, pp. 1281-306.

Kaltenbrunner, A. and Painceira, J.P. (2016) International and Domestic Financialisation in Middle Income Countries: The Brazilian Experience. FESSUD Working paper seroes 146.

Kaltenbrunner, A \& Painceira, J.P (2018a). Subordinated Financial Integration and Financialisation in Emerging Capitalist Economies: The Brazilian Experience, New Political Economy, 23:3, 290-313.

Kaltenbrunner, A \& Painceira, J.P (2018b). Financierizacion en America Latina: implicacancias de la integracion financier subordinada. In: Abeles, M., Caldentey, E.P., 
\& Valdecantos, S. (editors) (2018). Estudios sobre financierizacion en America Latina. CEPAL, Impreso de Naciones Unida, Santiago.

Karwowski, E. (2012). Financial Operations of South African Listed Firms: Growth and Financial Stability in an Emerging Market Setting. iii conferencia international do ieSe, Mozambique September.

Karwowski, E. \& Stockhammer, E. (2017). Financialisation in emerging economies: a systematic overview and comparison with Anglo-Saxon economies, Economic and Political Studies, 5:1, 60-86

Kilian C (2018) Purpose, Principles and Profit - A Critique of the Commercialisation of Residential Aged Care Services in New Zealand. Doctoral dissertation. Auckland, Auckland University of Technology.Klink J and Denaldi R (2014) On financialization and state spatial fixes in Brazil. A geographical and historical interpretation of the housing program My House My Life. Habitat International 44: 220-226.

Klink $\mathrm{J}$ and Stroher LEM (2017) The making of urban financialization? An exploration of Brazilian urban partnership operations with building certificates. Land Use Policy 69: 519-528.

Keynes, J. M. (1929). The German transfer problem. The Economic Journal, 39(153), 1-7

Kutz W and Lenhardt J (2016) "Where to put the spare cash?" Subprime urbanization and the geographies of the financial crisis in the Global South. Urban Geography 37(6): 926-948.

Langley, P. (2008). Financialization and the consumer credit boom. Competition \& Change, 12(2), 133-147,

Lapavitsas, C. (2009a). Financialisation embroils developing countries. The Broker, accessed online 30-10-2018: http://www.thebrokeronline.eu/Blogs/Redevelopingfinance/Financialisation-embroils-developing-countries

Lapavitsas, C. (2009b). Financialisation embroils developing countries. Papeles de Europa, 19: $108-139$

Lees, L., T. Slater \& E. Wyly (2008), Gentrification. New York: Routledge.

Lim, J.J., Mohapatra, S., \& Stocker, M. (2014). Tinker, Taper, QE, Bye? The effect of quantitative easing on financial flows to developing countries. Policy Research Working Paper 6820, World Bank,

López-Morales E (2016) A Multidimensional Approach to Urban Entrepreneurialism, Financialization, and Gentrification in the High-Rise Residential Market of Inner Santiago, Chile. Research in Political Economy 31: 79-105.

Marques E and Rodrigues L (2013) O Programa Minha Casa Minha Vida na metrópole paulistana: atendimento habitacional e padrões de segregação. Revista Brasileira de Estudos Urbanos e Regionais 15(2): 159-178.

McCauley, R., P. McGuire and V. Shushko (2015). "Dollar Credit to Emerging Economies." BIS Quarterly Review December 2015: 27-41.

Mendel M (2016) Rental and Student Housing - Emerging Asset Classes in Poland. http://www.reas.pl/en/commentaries/rental-and-student-housing-emerging-assetclasses-in-poland (accessed, July 5, 2018).

Morgan, P.J. (2011). Impact of US Quantitative Easing Policy on Emerging Asia. ADBI Working Paper Series, accessed online 1-12-2018:

https://www.adb.org/sites/default/files/publication/156176/adbi-wp321.pdf

Mosciaro M (2018) The Real Estate/Financial Complex: The Cases of Brazil and Italy. PhD thesis. Politecnico di Milano \& KU Leuven, Milan/Leuven.

Mosciaro M, Pereira A and Aalbers MB (2019) The financialization of urban development: Speculation and public land in Porto Maravilha, Rio de Janeiro. In: Chu CL and He S (eds) The Speculative City: Emerging Forms and Norms of the Built Environment.

Nölke, A. and Claar, S. (2013). Varieties of capitalism in emerging economies. Transformation 81/82, 33-54.

Nölke, A., Ten Brink, T., Claar, S., and May, C. (2015). Domestic structures, foreign economic policies and global economic order: Implications from the rise of large emerging economies. European Journal of International Relations, 21(3), 538-567. 
Painceira, J.B. (2008). Developing Countries in the Era of Financialisation: From Deficit Accumulation to Reserve Accumulation. Department of Economics, School of Oriental and African Studies. Research on Money and Finance Discussion Papers, N 4.

Painceira, J.P. (2010). The Financial Crisis of 2007-09 and Emerging Countries: The Political Economy Analysis of Central Banks in the Brazilian and Korean Economies. Competition and Change, 14, pp. 271-95.

Painceira, J.P. (2012). 'Financialisation, Reserve Accumulation, and Central Banking in Emerging Economies: Banks in Brazil and Korea', Research on Money and Finance Discussion Papers, 38, Available from: http://www.researchonmoneyandfinance.org/index.php/publication/discussion-papers.

Payne, G. (1989). Informal housing and land subdivisions in Third World cities: a review of the literature. Oxford, UK: Centre for Development and Environmental Planning.

Pereira A (2017) The financialization of housing: new frontiers in Brazilian cities. International Journal of Urban and Regional Research 41(4): 604-622.

Pósfai Z and Nagy G (2017) Crisis and the reproduction of core-periphery relations on the Hungarian housing market. European Spatial Research and Policy 24(2): 17-38.

Powell, J. (2013). Subordinate Financialisation: a Study of Mexico and its Non-Financial Corporations. SOAS, University of London.

Revington N and August M (2018) Making a market for itself: The emergent financialization of student housing in Canada. Manuscript submitted for publication.

Rodik P and Žitko M (2015) Financialization, Household Debt and New Vulnerabilities in Post-Socialist Societies. In: Radoevi D and Cvijanovi V (eds) Financialisation and Financial Crisis in South-Eastern European Countries. Frankfurt: Peter Lang, 49-70.

Rodrik, D (2006). The Social Cost of Foreign Exchange Reserves. International Economic Journal 20(3) 253-266.

Rodrigues, J., A.C. Santos, and N. Teles (2016) Semi-Peripheral Financialization: The Case of Portugal. Review of International Political Economy 23(3):480-510.

Rolnik R (2013) Late neoliberalism: The financialization of homeownership and housing rights. International Journal of Urban and Regional Research 37(3): 1058-66.

Rolnik R (2015) A Guerra dos Lugares: A Colonização da Terra e da Moradia na era das Finanças. São Paulo: Boitempo.

Ronald R (2008) The Ideology of Home Ownership Homeowner Societies and the Role of Housing. Basingstoke: Palgrave Macmillan.

Rosenberg, J. (2013) The 'philosophical premises' of uneven and combined development. Review of International Studies 39:3: 569-597.

Royer L (2014) Financeirização da Política Habitacional. São Paulo: Annablume.

Sanfelici D (2013) A metrópole sob o ritmo das finanças: implicações socioespaciais da expansão imobiliária no Brasil. PhD thesis. Universidade de São Paulo. Available at http://www.teses.usp.br/teses/disponiveis/8/8136/tde-07012014-093205/en.php (accessed, July 5, 2018).

Sanfelici D and Halbert L (2018) Financial market actors as urban policy-makers: the case of real estate investment trusts in Brazil. Urban Geography DOI:1080/02723638.2018.1500246.

Schneider BR (2013) Hierarchical Capitalism: Business, Labour, and the Challenge of Equitable Development in Latin America. New York, NY: Cambridge University Press.

Smart $A$ and Lee $\mathrm{J}$ (2003) Financialization and the role of real estate in Hong Kong's regime of accumulation. Economic Geography 79(2): 153-171.

Soares IO, de Carvalho AWB, Ribeiro Filho GB and de Almeida Pinto NM (2017) Interesses especulativos, atuação do Estado e direito à cidade: o caso do programa "Minha Casa Minha Vida" em Uberaba (MG). Revista Brasileira de Gestão Urbana 5(1): 119-131.

Soederberg, S. (2014) Debtfare States and the Poverty Industry: Money, Discipline and the Surplus Population. London: Routledge.

Soederberg S (2015) Subprime housing goes south: Constructing securitized mortgages for the poor in Mexico. Antipode 47(2): 481-499.

Strange, S. (1971) 'The politics of international currencies', World Politics 23(2): 215-31. 
Strange, S. (1998) Mad Money, Manchester: Manchester University Press.

Teresa BF (2016) Managing fictitious capital: The legal geography of investment and political strugglein rental housing in New York City. Environment and Planning A 48(3): 465484.

Thorsten, B., Demirgüç-Kunt, A \& Levine, R. (2000). A New Database on Financial Development and Structure. World Bank Economic Review 14, 597-605.

Thorsten, B., Demirgüç-Kunt, A \& Levine, R. (2009). Financial Institutions and Markets across Countries and over Time Data and Analysis. World Bank, Policy Research Working Paper 4943. Accessed online 1-11-2018:

https://openknowledge.worldbank.org/bitstream/handle/10986/4154/WPS4943.pdf

Trotsky, L. ([1930] 2017). The History of the Russian Revolution. Ebook, Accessed online 612-2018: https://www.marxists.org/archive/trotsky/1930/hrr/index.htm

Turkish statistical institute (2013) Population and housing census 2011. Accessed online 1511-2018: http://www.turkstat.gov.tr/PreHaberBultenleri.do?id=15843

UN Special Rapporteur on the Right to Adequate Housing (2012) The Impact of Housing Finance. Report A/67/286: https://www.ohchr.org/Documents/lssues/Housing/A-67286.pdf (accessed September 4, 2018).

UN Special Rapporteur on the Right to Adequate Housing (2017) The Financialization of Housing.

Report

$\mathrm{A} / \mathrm{HRC} / 34 / 51$ :

http://www.unhousingrapp.org/assets/documents/Thematic-Report-3-The-

Financialization-of-Housing.pdf (accessed September 4, 2018).

Uwe Becker (2013) Measuring Change of Capitalist Varieties: Reflections on Method, Illustrations from the BRICs. New Political Economy, 18(4), 503-532

Van der Linden, J.J. (1986). The sites and services approach reviewed: solution or stopgap to the Third World housing shortage? Alderschot: Gower.

Van der Linden, M. (2007). M The 'Law' of Uneven and Combined Development: Some Underdeveloped Thoughts. Historical Materialism 15, 145-165

Villosio, C. 1995. Mercato del credito, proprietà della casa, risparmio delle famiglie. Annali della Fondazione Einaudi 29: 213-248..

Wainwright T (2012) Building new markets: Transferring securitization, bond-rating, and a crisis from the US to the UK. In: Aalbers MB (ed.) Subprime Cities: The Political Economy of Mortgage Markets. Oxford: Wiley-Blackwell, 97-119.

Wainwright T and Manville G (2017) Financialization and the third sector: innovation in social housing bond markets. Environment and Planning A 49(4): 819-838.

Waldron R (2018) Capitalizing on the State: The Political Economy of Real Estate Investment Trusts and the 'Resolution' of the Crisis. Geoforum 90: 206-218.

Wijburg $G$ and Aalbers MB (2017) The alternative financialization of the German housing market. Housing Studies 32(7): 968-989.

Wijburg G, Aalbers MB and Heeg S (2018) The Financialization of Rental Housing 2.0: Releasing Housing into the Privatized Mainstream of Capital Accumulation. Antipode 50(4): 1098-1119.

World Bank (2009). Financial Institutions and Markets across Countries and over Time. Policy Research Working Paper, 4943.

World Bank (2012). Benchmarking Financial Systems around the World. Policy Research Working Paper, 6175.

Yardeni Research (2018). Global economic briefing: Central banks balance sheets. Accessed online 14-3-2018: https://www.yardeni.com/pub/peacockfedecbassets.pdf

Zapata GP (2018) Transnational migration, remittances and the financialization of housing in Colombia. Housing Studies 33(3): 343-360. 